\title{
Characteristics of the carcass of goats of different genotypes fed pineapple (Ananas comosus L.) stubble hay
}

\author{
Rosângela Maria Brito Lima', Wandrick Hauss de Sousa ${ }^{2}$, Ariosvaldo Nunes de Medeiros ${ }^{3}$, \\ Marcílio Fontes Cezar ${ }^{4}$, Felipe Queiroga Cartaxo ${ }^{5}$, Severino Gonzaga Neto ${ }^{3}$, Roberto Germano \\ Costa $^{3}$, Geovergue Rodrigues de Medeiros $^{6}$
}

\footnotetext{
${ }^{1}$ Instituto Federal de Educação, Ciência e Tecnologia do Sertão Pernambucano, Floresta, PE, Brasil.

${ }^{2}$ Empresa Estadual de Pesquisa Agropecuária da Paraíba, João Pessoa, PB, Brasil.

${ }^{3}$ Universidade Federal da Paraíba, Centro de Ciências Agrárias, Areia, PB, Brasil.

${ }^{4}$ Universidade Federal de Campina Grande. Centro de Saúde e Tecnologia Rural, Patos, PB, Brasil.

${ }^{5}$ Universidade Estadual da Paraíba, Departamento de Ciências Humanas e Agrárias, Catolé do Rocha, PB, Brasil.

${ }^{6}$ Instituto Nacional do Semiárido, Campina Grande, PB, Brasil.
}

\begin{abstract}
The effect of the substitution of Tifton hay $(0,33,66,100 \mathrm{~g} / 100 \mathrm{~g}$ ) for pineapple (Ananas comosus L.) stubble hay was evaluated in the characteristics of the carcasses of goats of an unknown breed (UB) in feedlot. Thirty-two bucks with an average initial live weight of $17.5 \pm 1.3 \mathrm{~kg}$, at approximately 150 days of age, were housed in individual stalls provided with feeding and drinking troughs. The animals were distributed in a completely randomized design with four treatments and eight replications. There was a quadratic effect on the weights of hot carcass and cold carcass, empty body, and loin eye area. A linear increase was observed for losses by carcass cooling. The weights of commercial cuts and the weights of total muscle, total bone, intramuscular fat, and total fat decreased linearly. All morphometric measurements were influenced by the inclusion of pineapple stubble hay in the diets. Substitution of Tifton hay for pineapple stubble hay at the level of $33 \mathrm{~g} / 100 \mathrm{~g}$ improves the carcasses of UB goats qualitatively and quantitatively.
\end{abstract}

Key Words: compactness index, loin eye area, morphometric measurements, subcutaneous fat thickness, waste cultures

\section{Introduction}

Goat raising in the Brazilian Northeast is an important economic and social activity, especially for small producers, due to the high adaptability of goats to the soil and climate conditions of the region (Bezerra et al., 2010). The confinement of goats, thus, may be a feasible alternative of raising, especially when it is aimed at intensifying the production system, and improve meat supply and carcass quality (Dias et al., 2008).

Evaluating carcasses, Cartaxo et al. (2011) reported that loin eye area, subcutaneous fat thickness, and marbling are characteristics related to daily weight gain, carcass yield, finishing, meat flavor and juiciness, whereas tissue composition is based on the amount of muscle, and adipose and bone tissues (Monte et al., 2007). Moreover, in countries where meat is sold at retail, the content of each cut is an important factor that determines its value (Mahgoub and Lu, 1998).

Received April 3, 2013 and accepted August 28, 2014 Corresponding author: rosangela.brito@ifsertao-pe.edu.br http://dx.doi.org/10.1590/S1806-92902015000200002

Copyright (@) 2015 Sociedade Brasileira de Zootecnia. This is an Open Access article distributed under the terms of the Creative Commons Attribution Non-Commercial License, which permits unrestricted non-commercial use, distribution, and reproduction in any medium, provided the original work is properly cited.
According to Hadjipanayiotou (1987), feeding in intensive production systems represents 55 to $75 \%$ of the total production costs. Thus, evaluating different diets and their effects becomes essential in production systems.

A strategy to reduce feeding costs is to use agroindustrial by products or regional feeds, particularly roughages, capable not only of perpetuating in the semiarid region, but also producing large amounts of hay per unit area (Moreira et al., 2008). Among these feeds is pineapple plant debris, which can be consumed by goats in the form of hay. However, little is known about the carcass characteristics of animals fed pineapple plant debris.

The objective of this research was to evaluate substitution of Tifton hay for pineapple stubble hay on the characteristics of the carcasses of goats of an unknown breed.

\section{Material and Methods}

Thirty-two bucks of an unknown breed (UB), with an initial weight of $17.5 \pm 1.3 \mathrm{~kg}$, at approximately 150 days of age, were used. They were weighed, identified, vaccinated against clostridiosis and dewormed with ivermectin at $1 \%$, and then housed in individual stalls $(0.80 \times 1.20 \mathrm{~m})$ provided with feeding and drinking troughs. 
The complete diets, supplied twice a day (Table 1), were formulated to meet the nutritional requirements for growth recommended by the NRC (2007), aiming at weight gains of $150 \mathrm{~g} /$ day. The experimental period had the duration of 90 days, 14 of which were intended for the adaptation of the animals to environment, handling, and diet. The goats were weighed every 14 days according to the experimental periods.

For the process of preparation of the pineapple stubble hay, the pineapple plants were processed through a forage machine and exposed to the environment for dehydration.

The Tifton hay, of the tifton-85 (Cynodon dactylon) variety, was acquired commercially.

At the end of the experimental period, the animals were deprived of solids for 18 hours, and then weighed to determine their slaughter weight (SW), and subsequently slaughtered.

At slaughter, the animals were stunned by cerebral concussion in the atlas-occipital region, and then suspended by the hind legs, followed by bleeding by severing the jugular veins and carotid arteries. After bleeding and skinning, the gastrointestinal tract (GIT), skin, and viscera were removed. The viscera were weighed, full and empty, to determine the contents of the gastrointestinal tract (GITC); head, legs and genitals were removed.

The empty body weight (EBW) was obtained as the difference between slaughter weight (SW) and gastrointestinal content weight.

The carcasses were weighed to obtain the hot carcass weight $(\mathrm{HCW})$, and then packed in polyethylene bags and stored in a cold room at $4{ }^{\circ} \mathrm{C}$, where they remained for $24 \mathrm{~h}$.
Once chilled, the carcasses were weighed to obtain the cold carcass weight (CCW). The hot carcass yield (HCY) and cold carcass yield (CCY) were determined with the following formulas: $\mathrm{HCY}=(\mathrm{HCW} / \mathrm{SW}) \times 100$, and $\mathrm{CCY}=$ $(\mathrm{CCW} / \mathrm{SW}) \times 100$. The biological yield $(\mathrm{BIOY})$ was also evaluated, calculated as follows: BIOY $(\mathrm{g} / 100 \mathrm{~g})=(\mathrm{HCW} /$ EBW) $\times 100$. The weight loss by cooling $($ WLC) was determined by the following expression: WLC $(\mathrm{g} / 100 \mathrm{~g})=$ $(\mathrm{HCW}-\mathrm{CCW} / \mathrm{HCW}) \times 100$.

Subsequently, the qualitative characteristics of the carcasses were determined in the refrigerated environment by evaluations of conformation and exterior visual impressions of the carcass and the amount of kidney-pelvic fat.

The carcass conformation was evaluated with emphasis on anatomical regions (leg, rump, loin, shoulder, and their muscles) and the exterior visual impressions of the carcass were performed with emphasis on thickness and distribution of fat in relation to the skeleton according to the categories and scores ( 1 to 5) demonstrated by Cezar and Sousa (2007), as well as by determining the amount of kidney-pelvic fat. After this procedure, the carcasses were split longitudinally.

To determine marbling, visual examination was performed on the surface of the longissimus dorsi, and scores of 1 to 3 (nonexistent, little, and medium) were given, according to the methodology described by Cezar and Sousa (2007).

A transversal cut was made on the left half-carcass between the 12th and 13th ribs, exposing the transverse cross section of the longissimus dorsi muscle, and the loin eye area (LEA) was determined with the use of clear plastic

Table 1 - Nutritional and chemical composition of the experimental diets, on a dry matter basis

\begin{tabular}{|c|c|c|c|c|}
\hline \multirow{2}{*}{ Ingredients (g/kg DM) } & \multicolumn{4}{|c|}{ Levels of pineapple stubble hay (g/100 g) } \\
\hline & 0 & 33 & 66 & 100 \\
\hline Pineapple stubble hay & 0.00 & 165.0 & 335.0 & 500.0 \\
\hline Tifton hay & 500.0 & 335.0 & 165.0 & 0.00 \\
\hline Ground corn & 380.0 & 372.0 & 300.0 & 180.0 \\
\hline Soybean meal & 71.0 & 98.0 & 85.0 & 70.0 \\
\hline Wheat bran & 0.00 & 0.00 & 80.0 & 213.0 \\
\hline Vegetable oil & 20.0 & 1.00 & 0.00 & 0.00 \\
\hline Urea & 15.0 & 15.0 & 15.0 & 17.0 \\
\hline Limestone & 10.0 & 10.0 & 15.0 & 15.0 \\
\hline Mineral salt & 4.00 & 4.00 & 5.00 & 5.00 \\
\hline \multicolumn{5}{|c|}{ Chemical composition (g/kg DM) } \\
\hline Dry matter & 870.3 & 865.0 & 863.1 & 861.6 \\
\hline Ash & 55.8 & 53.9 & 58.7 & 59.8 \\
\hline Crude protein & 150.0 & 158.0 & 156.0 & 162.0 \\
\hline Ether extract & 39.6 & 27.3 & 32.4 & 38.3 \\
\hline Neutral detergent fiber & 346.8 & 357.9 & 389.8 & 438.0 \\
\hline Acid detergent fiber & 254.1 & 238.8 & 228.7 & 224.8 \\
\hline Total carbohydrates & 754.6 & 760.8 & 752.9 & 744.4 \\
\hline Total digestible nutrients & 708.9 & 702.1 & 702.5 & 696.5 \\
\hline
\end{tabular}


wrap, by means of which the maximum width (A) and the maximum depth (B) were obtained with a millimeter ruler to determine the area, according to the following formula: LEA $=(A / 2 * B / 2) \pi$. Subcutaneous fat thickness (SFT) was measured with a digital caliper and determined by the depth of fat over the 12th rib.

On the right half-carcass, the length of the inner carcass was measured using a tape measure to calculate the carcass compactness index: $\mathrm{CCI}=\mathrm{CCW} /$ length of the inner carcass (LIC), according to Yáñez et al. (2004). The leg compactness index (LCI) was determined as the rump width in relation to the leg length.

Then, the following morphometric measurements were performed using a measure tape and a hipometer: chest width, rump width, chest depth, chest circumference, rump circumference, leg circumference, carcass length, inner-carcass length, and leg length, all expressed in centimeters.

After that, the right half carcass was sectioned into five anatomical regions (commercial cuts): neck, shoulder, ribs, loin, and leg, according to the methodology described by Colomer-Rocher (1986). These cuts were individually weighed and quantified in percentage of the right halfcarcass.

The legs were packed in plastic bags, properly sealed and identified, and stored in a freezer at $-20^{\circ} \mathrm{C}$ for one week.

The tissue composition of the carcass was estimated indirectly, and instead of separating the bones, muscles and fats in the entire carcass, the proportion of these tissues in the leg was used a parameter which holds high correlation with the results obtained with the dissection of the carcass (Piola Junior et al., 2009).

For this purpose, the legs were removed from the freezer, weighed, thawed at $10{ }^{\circ} \mathrm{C}$ for $24 \mathrm{~h}$, and dissected according to the methodology described by Silva Sobrinho (1999), to determine the proportions of muscles, bone, and fat, and subsequent ratios of muscle:bone and muscle:fat.

The leg muscularity index (LMI) was determined after dissecting and weighing the five muscles that cover the femur - femoral biceps, semitendinosus, adductor, semimembranosus, and femoral quadriceps and the femur completely cleaned. For such, the formula described by Purchas et al. (1991) was used:

$$
L M I=\frac{\sqrt{P 5 M / L F}}{L F}
$$

in which P5M is the weight (g) of the five muscles and LF is the length $(\mathrm{cm})$ of the femur.

The statistical design was completely randomized, with four treatments, at levels of substitution of Tifton hay for pineapple stubble hay $(0,33,66$, and $100 \mathrm{~g} / 100 \mathrm{~g})$ and eight replications.

The data were subjected to analysis of variance with polynomial regression, considering the levels of pineapple stubble hay.

For the analyses of variance, two mathematical models were used, in which the initial weights (p) and slaughter weight (SW) were used as a covariate.

$$
\text { (1) } \mathrm{Y}_{i j}=\mu+\mathrm{t}_{i}+\mathrm{p}_{j}+\mathrm{e}_{i j} \text {, }
$$

in which: $\mathrm{Y}_{i j}=$ observed value of each dependent variable referring to treatment $i$, in replication $j ; \mu=$ overall mean; $\mathrm{t}_{i}=$ effect of treatment $i, i=(1,2,3$ and 4$) ; \mathrm{p}_{j}=$ effect of the initial weight covariate; and $\mathrm{e}_{i j}=$ random error associated with each observation.

The initial weight was included as a covariate for the variables of Table 2, except HCY, CCY and BIOY, in which the initial weight covariate (p) was not significant, and was thus removed from the model.

$$
\text { (2) } \mathrm{Y}_{i j}=\mu+\mathrm{t}_{i}+\mathrm{pa}_{j}+\mathrm{e}_{i j} \text {, }
$$

\begin{tabular}{|c|c|c|c|c|c|c|c|c|}
\hline \multirow{2}{*}{ Variables } & \multicolumn{4}{|c|}{ Levels of pineapple stubble hay $(\mathrm{g} / 100 \mathrm{~g})$} & \multirow{2}{*}{$\mathrm{X} \pm \mathrm{SD}$} & \multicolumn{2}{|c|}{ Regression } & \multirow{2}{*}{$\mathrm{R}^{2}$} \\
\hline & 0 & 33 & 66 & 100 & & $\mathrm{~L}$ & Q & \\
\hline Initial weight $(\mathrm{kg})$ & 18.10 & 18.70 & 17.60 & 15.90 & $17.73 \pm 1.91$ & - & - & - \\
\hline Slaughter weight (kg) & 25.36 & 25.90 & 22.42 & 20.17 & $23.46 \pm 2.68$ & 1 & ns & 81.31 \\
\hline Hot carcass weight $(\mathrm{kg})$ & 12.74 & 14.12 & 11.12 & 9.80 & $11.94 \pm 2.29$ & ns & 2 & 82.26 \\
\hline Cold carcass weight (kg) & 12.52 & 13.83 & 10.82 & 9.54 & $11.68 \pm 2.27$ & ns & 3 & 82.32 \\
\hline Empty body weight (kg) & 21.17 & 22.85 & 18.82 & 17.01 & $19.96 \pm 3.16$ & ns & 4 & 83.51 \\
\hline Hot carcass yield (g/100 g) & 49.80 & 52.52 & 50.17 & 49.66 & $50.54 \pm 3.66$ & ns & ns & - \\
\hline Cold carcass yield (g/100 g) & 48.97 & 51.45 & 48.80 & 48.38 & $49.40 \pm 3.58$ & ns & ns & - \\
\hline Biological yield (g/100 g) & 60.12 & 61.68 & 59.32 & 57.28 & $59.60 \pm 3.65$ & ns & $\mathrm{ns}$ & - \\
\hline Loss by cooling (g/100 g) & 1.68 & 2.03 & 2.71 & 2.58 & $2.25 \pm 0.75$ & 5 & $\mathrm{~ns}$ & 82.23 \\
\hline
\end{tabular}

Table 2 - Weights, yields and cooling loss of goat carcasses according to the levels of pineapple stubble hay in the diet

$\mathrm{X} \pm \mathrm{SD}$ - mean and standard deviation; L - linear; $\mathrm{Q}$ - quadratic; $\mathrm{R}^{2}$ - coefficient of determination; ns - not significant.

${ }^{1} \hat{\mathrm{Y}}=26.344985-0.055627 ; \mathrm{P}<0.01$.

${ }^{2} \hat{\mathrm{Y}}=12.741500+0.168798 \mathrm{x}-0.004764 \mathrm{x}^{2} ; \mathrm{P}<0.05$.

${ }^{3} \hat{\mathrm{Y}}=12.528300+0.165462 \mathrm{x}-0.004731 \mathrm{x}^{2} ; \mathrm{P}<0.05$.

${ }^{4} \hat{\mathrm{Y}}=21.170625+0.217696 \mathrm{x}-0.006254 \mathrm{x}^{2} ; \mathrm{P}<0.05$

${ }^{5} \hat{\mathrm{Y}}=1.686587-0.005428 \mathrm{x} ; \mathrm{P}<0.05$. 
in which: $\mathrm{Y}_{i j}=$ observed value of each dependent variable referring to treatment $i$, in replication $j ; \mu=$ overall mean; $\mathrm{t}_{i}=$ effect of treatment $i, i=(1,2,3$ and 4$) ; \mathrm{pa}_{j}=$ effect of the slaughter weight covariate; and $\mathrm{e}_{i j}=$ random error associated with each observation.

The slaughter weight was included as a covariate for the variables of Tables 3, 4, 6 and 7, except for kidney- pelvic fat, marbling (Table 3); leg compactness index (LCI), leg muscularity index (LMI) (Table 4); percentage of leg, loin, rib, shoulder and neck (Table 6); other tissues, percentage of muscle, bone, fat, other tissues, and muscle: bone and muscle:fat ratio (Table 7), in which a covariate slaughter weight (SW) was not significant, and was thus removed from the model.

Table 3 - Qualitative characteristics of the goats according to the levels of pineapple stubble hay

\begin{tabular}{|c|c|c|c|c|c|c|c|c|}
\hline \multirow{2}{*}{ Variables } & \multicolumn{4}{|c|}{ Levels of pineapple stubble hay $(\mathrm{g} / 100 \mathrm{~g})$} & \multirow{2}{*}{$\mathrm{X} \pm \mathrm{SD}$} & \multicolumn{2}{|c|}{ Regression } & \multirow{2}{*}{$\mathrm{R}^{2}$} \\
\hline & 0 & 33 & 66 & 100 & & $\mathrm{~L}$ & Q & \\
\hline Conformation & 2.06 & 1.99 & 1.61 & 1.42 & $1.77 \pm 0.46$ & 2 & ns & 94.28 \\
\hline Exterior visual impressions & 1.65 & 1.40 & 1.13 & 1.07 & $1.31 \pm 0.29$ & 3 & ns & 94.20 \\
\hline Kidney-pelvic fat & 2.29 & 2.54 & 2.27 & 2.20 & $2.32 \pm 0.45$ & ns & ns & - \\
\hline Marbling $(1 \text { to } 3)^{1}$ & 1.25 & 1.21 & 1.21 & 1.19 & $1.21 \pm 0.25$ & ns & ns & - \\
\hline
\end{tabular}

$\mathrm{X} \pm \mathrm{SD}$ - mean and standard deviation; L - linear; Q - quadratic; $\mathrm{R}^{2}$ - coefficient of determination; ns - not significant.

${ }^{1}$ Marbling: 1- nonexistent; 2 - little; 3 - medium (Cezar and Sousa, 2007).

${ }^{2} \hat{\mathrm{Y}}=2.113644-0.006907 \mathrm{x} ; \mathrm{P}<0.01$.

${ }^{3} \hat{\mathrm{Y}}=1.612247-0.666025 \mathrm{x} ; \mathrm{P}<0.01$

Table 4 - Morphometric measurements of the goat carcasses according to the levels of pineapple stubble hay in the diet

\begin{tabular}{|c|c|c|c|c|c|c|c|c|}
\hline \multirow{2}{*}{ Variables } & \multicolumn{4}{|c|}{ Levels of pineapple stubble hay $(\mathrm{g} / 100 \mathrm{~g})$} & \multirow{2}{*}{$\mathrm{X} \pm \mathrm{SD}$} & \multicolumn{2}{|c|}{ Regression } & \multirow{2}{*}{$\mathrm{R}^{2}$} \\
\hline & 0 & 33 & 66 & 100 & & $\mathrm{~L}$ & Q & \\
\hline Chest width (cm) & 10.80 & 11.00 & 10.60 & 10.10 & $10.62 \pm 0.80$ & 1 & ns & 70.33 \\
\hline Rump width (cm) & 13.50 & 13.40 & 12.50 & 11.90 & $12.82 \pm 1.50$ & 2 & ns & 93.09 \\
\hline Chest depth (cm) & 24.60 & 25.10 & 24.20 & 23.50 & $24.35 \pm 1.25$ & 3 & ns & 64.78 \\
\hline Chest circumference $(\mathrm{cm})$ & 62.10 & 63.20 & 60.60 & 59.10 & $61.25 \pm 2.80$ & 4 & ns & 70.60 \\
\hline Rump circumference (cm) & 44.60 & 44.70 & 43.10 & 40.40 & $44.13 \pm 3.10$ & 5 & ns & 84.07 \\
\hline Leg circumference $(\mathrm{cm})$ & 31.30 & 31.50 & 30.10 & 28.90 & $30.45 \pm 2.44$ & 6 & ns & 85.31 \\
\hline Carcass length $(\mathrm{cm})$ & 55.40 & 56.40 & 54.40 & 51.80 & $54.50 \pm 2.82$ & ns & 7 & 97.29 \\
\hline Inner carcass length $(\mathrm{cm})$ & 61.40 & 61.10 & 59.60 & 57.50 & $59.90 \pm 3.00$ & 8 & ns & 91.66 \\
\hline Leg length $(\mathrm{cm})$ & 39.47 & 40.20 & 39.10 & 37.60 & $39.09 \pm 1.61$ & ns & 9 & 96.87 \\
\hline
\end{tabular}

$\mathrm{X} \pm \mathrm{SD}$ - mean and standard deviation; L - linear; $\mathrm{Q}$ - quadratic; $\mathrm{R}^{2}$ - coefficient of determination; ns - not significant.

${ }^{1} \hat{\mathrm{Y}}=10.999824-0.007534 \mathrm{x} ; \mathrm{P}<0.05$.

${ }^{2} \hat{\mathrm{Y}}=13.677158-0.017128 \mathrm{x} ; \mathrm{P}<0.01$.

${ }^{3} \hat{\mathrm{Y}}=24.979417-0.012651 \mathrm{x} ; \mathrm{P}<0.05$.

${ }^{4} \hat{\mathrm{Y}}=62.986617-0.034906 ; \mathrm{P}<0.01$

${ }^{5} \hat{\mathrm{Y}}=45.327368-0.42761 \mathrm{x} ; \mathrm{P}<0.01$.

${ }^{6} \hat{\mathrm{Y}}=31.737098-0.025871 ; \mathrm{P}<0.05$.

${ }^{7} \hat{Y}=55.527560+0.041197 x-0.000796 x^{2} ; P<0.05$.

${ }^{8} \hat{Y}=61.875733-0.039713 x ; P<0.01$.

${ }^{9} \hat{\mathrm{Y}}=39.545964+0.029267 \mathrm{x}-0.000494 \mathrm{x}^{2} ; \mathrm{P}<0.05$

Table 5 - Loin eye area, subcutaneous fat thickness and indexes of muscularity in the goat carcasses according to the levels of pineapple stubble hay in the diet

\begin{tabular}{|c|c|c|c|c|c|c|c|c|}
\hline \multirow{2}{*}{ Variables } & \multicolumn{4}{|c|}{ Levels of pineapple stubble hay $(\mathrm{g} / 100 \mathrm{~g})$} & \multirow{2}{*}{$\mathrm{X} \pm \mathrm{SD}$} & \multicolumn{2}{|c|}{ Regression } & \multirow{2}{*}{$\mathrm{R}^{2}$} \\
\hline & 0 & 33 & 66 & 100 & & $\mathrm{~L}$ & Q & \\
\hline $\operatorname{LEA}\left(\mathrm{cm}^{2}\right)$ & 8.11 & 9.73 & 8.43 & 7.96 & $8.56 \pm 1.52$ & ns & 1 & 62.69 \\
\hline $\mathrm{SFT}(\mathrm{mm})$ & 1.74 & 1.37 & 1.26 & 1.32 & $1.42 \pm 0.45$ & 2 & ns & 67.69 \\
\hline $\mathrm{CCI}(\mathrm{g} / \mathrm{cm})$ & 0.20 & 0.22 & 0.18 & 0.17 & $0.19 \pm 0.03$ & 3 & ns & 60.31 \\
\hline LCI $(\mathrm{cm})$ & 0.34 & 0.33 & 0.32 & 0.31 & $0.32 \pm 0.03$ & ns & $\mathrm{ns}$ & - \\
\hline $\mathrm{LMI}(\mathrm{g} / \mathrm{cm})$ & 0.01 & 0.01 & 0.01 & 0.01 & $0.01 \pm 0.0008$ & ns & ns & - \\
\hline
\end{tabular}

$\mathrm{X} \pm \mathrm{SD}$ - mean and standard deviation; L - linear; $\mathrm{Q}$ - quadratic; $\mathrm{R}^{2}$ - coefficient of determination; ns - not significant.

LEA - loin eye area; SFT - subcutaneous fat thickness; CCI - carcass compactness index; LCI - leg compactness index; LMI - leg muscle index.

${ }^{1} \hat{\mathrm{Y}}=8.308679+0.041071 \mathrm{x}-0.000463 \mathrm{x}^{2} ; \mathrm{P}<0.05$.

${ }^{2} \hat{\mathrm{Y}}=1.630573-0.004101 \mathrm{x} ; \mathrm{P}<0.05$.

${ }^{3} \hat{\mathrm{Y}}=0.213648-0.000368 \mathrm{x} ; \mathrm{P}<0.01$. 
Table 6 - Weights and percentages of the commercial cuts of the goats according to the levels of pineapple stubble hay in the diet

\begin{tabular}{|c|c|c|c|c|c|c|c|c|}
\hline \multirow{2}{*}{ Variables } & \multicolumn{4}{|c|}{ Levels of pineapple stubble hay $(\mathrm{g} / 100 \mathrm{~g})$} & \multirow{2}{*}{$\mathrm{X} \pm \mathrm{SD}$} & \multicolumn{2}{|c|}{ Regression } & \multirow{2}{*}{$\mathrm{R}^{2}$} \\
\hline & 0 & 33 & 66 & 100 & & $\mathrm{~L}$ & Q & \\
\hline Leg (kg) & 1.73 & 1.79 & 1.56 & 1.37 & $1.62 \pm 0.27$ & 1 & ns & 80.75 \\
\hline Loin (kg) & 0.76 & 0.81 & 0.67 & 0.58 & $0.71 \pm 0.13$ & 2 & ns & 76.89 \\
\hline Ribs (kg) & 1.55 & 1.76 & 1.41 & 1.27 & $1.50 \pm 0.32$ & 3 & ns & 54.57 \\
\hline Shoulder (kg) & 1.22 & 1.28 & 1.08 & 1.00 & $1.15 \pm 0.19$ & 4 & ns & 75.65 \\
\hline Neck (kg) & 0.80 & 0.91 & 0.77 & 0.72 & $0.80 \pm 0.13$ & 5 & $\mathrm{~ns}$ & 42.07 \\
\hline $\operatorname{Leg}(g / 100 \mathrm{~g})$ & 27.95 & 26.82 & 28.15 & 27.69 & $27.65 \pm 1.44$ & ns & ns & - \\
\hline Loin $(g / 100 \mathrm{~g})$ & 12.33 & 12.14 & 12.09 & 11.82 & $12.10 \pm 0.76$ & ns & ns & - \\
\hline Ribs (g/100 g) & 24.93 & 26.07 & 25.43 & 25.36 & $25.45 \pm 1.71$ & ns & ns & - \\
\hline Shoulder (g/100 g) & 19.68 & 19.06 & 19.61 & 20.14 & $19.62 \pm 1.01$ & ns & $\mathrm{ns}$ & - \\
\hline Neck $(g / 100 \mathrm{~g})$ & 13.08 & 13.60 & 13.99 & 14.55 & $13.81 \pm 1.43$ & 6 & ns & 99.58 \\
\hline
\end{tabular}

$\mathrm{X} \pm \mathrm{SD}$ - mean and standard deviation; $\mathrm{L}$ - linear; $\mathrm{Q}$ - quadratic; $\mathrm{R}^{2}$ - coefficient of determination; ns - not significant.

${ }^{1} \hat{\mathrm{Y}}=1.817059-0.003983 \mathrm{x} ; \mathrm{P}<0.01$.

${ }^{2} \hat{Y}=0.813572-0.002075 x ; P<0.01$.

${ }^{3} \hat{Y}=1.680779-0.003618 x ; P<0.01$

${ }^{4} \hat{Y}=1.276657-0.002584 x ; P<0.01$

${ }^{5} \hat{\mathrm{Y}}=0.864534-0.001197 \mathrm{x} ; \mathrm{P}<0.05$.

${ }^{6} \hat{\mathrm{Y}}=13.091301+0.014466 \mathrm{x} ; \mathrm{P}<0.05$.

Table 7 - Tissue composition of the leg of the UB goats according to the levels of pineapple stubble hay in the diet

\begin{tabular}{|c|c|c|c|c|c|c|c|c|}
\hline \multirow{2}{*}{ Variables } & \multicolumn{4}{|c|}{ Levels of pineapple stubble hay (g/100 g) } & \multirow{2}{*}{$\mathrm{X} \pm \mathrm{SD}$} & \multicolumn{2}{|c|}{ Regression } & \multirow{2}{*}{$\mathrm{R}^{2}$} \\
\hline & 0 & 33 & 66 & 100 & & $\mathrm{~L}$ & Q & \\
\hline Total muscle $(\mathrm{kg})$ & 1.14 & 1.18 & 1.00 & 0.89 & $1.06 \pm 0.20$ & 1 & ns & 79.38 \\
\hline Total bone $(\mathrm{kg})$ & 0.42 & 0.42 & 0.37 & 0.34 & $0.39 \pm 0.05$ & 2 & ns & 84.53 \\
\hline Subcutaneous fat $(\mathrm{kg})$ & 0.02 & 0.03 & 0.02 & 0.02 & $0.02 \pm 0.007$ & ns & ns & - \\
\hline Intramuscular fat (kg) & 0.03 & 0.03 & 0.02 & 0.02 & $0.02 \pm 0.01$ & 3 & ns & 92.23 \\
\hline Total fat $(\mathrm{kg})$ & 0.05 & 0.06 & 0.05 & 0.04 & $0.05 \pm 0.01$ & 4 & ns & 86.91 \\
\hline Other tissues $(\mathrm{kg})$ & 0.09 & 0.08 & 0.10 & 0.06 & $0.08 \pm 0.05$ & ns & ns & - \\
\hline Muscle (g/100 g) & 65.53 & 66.94 & 64.92 & 65.40 & $65.70 \pm 4.22$ & ns & ns & - \\
\hline Bone $(\mathrm{g} / 100 \mathrm{~g})$ & 24.26 & 24.19 & 24.34 & 25.75 & $24.64 \pm 1.93$ & ns & ns & - \\
\hline Fat $(\mathrm{g} / 100 \mathrm{~g})$ & 3.48 & 3.47 & 3.17 & 3.39 & $3.38 \pm 0.74$ & ns & ns & - \\
\hline Other tissues $(\mathrm{g} / 100 \mathrm{~g})$ & 5.06 & 4.56 & 6.74 & 4.37 & $5.18 \pm 3.10$ & ns & ns & - \\
\hline Muscle:bone ratio & 2.71 & 2.78 & 2.68 & 2.56 & $2.68 \pm 0.32$ & ns & ns & - \\
\hline Muscle:fat ratio & 19.68 & 20.50 & 20.97 & 19.63 & $20.20 \pm 3.89$ & ns & ns & - \\
\hline
\end{tabular}

$\mathrm{X} \pm \mathrm{SD}$ - mean and standard deviation; L - linear; $\mathrm{Q}$ - quadratic; $\mathrm{R}^{2}$ - coefficient of determination; ns - not significant.

${ }^{1} \hat{\mathrm{Y}}=1.194472-0.002742 \mathrm{x} ; \mathrm{P}<0.01$

${ }^{2} \hat{Y}=0.433480-0.000826 x ; P<0.01$.

${ }^{3} \hat{\mathrm{Y}}=0.033135-0.000097 \mathrm{x} ; \mathrm{P}<0.01$.

${ }^{4} \hat{\mathrm{Y}}=0.063025-0.0001723 \mathrm{x} ; \mathrm{P}<0.05$.

\section{Results}

The substitution of Tifton hay for pineapple stubble hay resulted in a decreasing linear effect $(\mathrm{P}<0.01)$ on slaughter weight (Table 2). This may have occurred due to the reduction of the initial weight of the goats as the levels of pineapple stubble hay were increased in the diets, reflecting in the slaughter weight.

Regarding the qualitative characteristics of the carcasses, there was a decreasing linear effect $(\mathrm{P}<0.01)$ on conformation, as well as on the exterior visual impressions (Table 3).

This decrease occurred in response to the reduction in slaughter weight and, consequently, the deficient muscular and adipose distribution, decisive parameters in the evaluation of these respective characteristics.
All of the morphometric measurements were influenced by the inclusion of pineapple stubble hay in the diets (Table 4).

Except for the lengths of the carcass and of the leg, which had quadratic effects $(\mathrm{P}<0.01)$, the other measurements chest width, rump width, chest depth, chest circumference, rump circumference, leg circumference, and inner carcass length - decreased linearly.

Despite the decreasing linear statistic results present in most of the morphometric measurements, the treatment with $33 \mathrm{~g} / 100 \mathrm{~g}$ seems to be the one that most influenced the morphometry of the animals.

The quadratic behavior $(\mathrm{P}<0.05)$ for loin eye area (Table 5) suggested that the goats fed the diet containing levels of substitution close to $33 \mathrm{~g} / 100 \mathrm{~g}$ of pineapple stubble hay had a greater quantity of muscle in the carcass. 
There was a decreasing linear effect $(\mathrm{P}<0.05)$ for the weights of commercial cuts, leg, loin, ribs, shoulder, and neck $(\mathrm{P}<0.01)$; however, the percentages of these cuts were not influenced $(\mathrm{P}>0.05)$ by the levels of pineapple stubble hay, except for the percentage of neck, which increased linearly $(\mathrm{P}<0.01)$ (Table 6).

The weights of total muscle, total bone, intramuscular fat $(\mathrm{P}<0.01)$, and total fat $(\mathrm{P}<0.05)$ decreased linearly with the substitution of the hays in the diet of the goats, while subcutaneous fat, other-tissues fat, the percentages of muscle, bone, fat, and other tissues, and the muscle:bone and muscle:fat ratios were not influenced $(\mathrm{P}>0.05)$ by the diets (Table 7).

\section{Discussion}

With the substitution of the hays in the diets (Table 2), the hot-carcass, cold-carcass, and empty-body weights had a quadratic effect $(\mathrm{P}<0.05)$ and the losses by cooling had an increasing linear effect $(\mathrm{P}<0.01)$.

The hot-carcass, cold-carcass and biological yields were not influenced $(\mathrm{P}>0.05)$ by the levels of substitution of Tifton hay for pineapple stubble hay.

It was observed that despite having different values between the significance of slaughter weight and weights of carcass, the values followed the same tendency and were influenced by the empty body weights, which showed quadratic significance following the weights of carcass.

The values for hot and cold carcass weights are within the expected for goats with these breed characteristics, UB, and type of feed utilized, and it is important to stress that good weights were reached for the commercial reality of the Northeast region of Brazil.

Despite not having a significant effect, it was noted that when the animals received the level of $33 \mathrm{~g} / 100 \mathrm{~g}$ of pineapple stubble hay in place of the Tifton hay, the hot-carcass, coldcarcass and biological yields resulted in higher numerical values for all of the variables when compared with the other levels. This fact demonstrates that the collection of data interfered with the result of significance and that this level can be recommended for use as part of the roughage for UB goats in feedlot, although a cost analysis is suggested to better verify its efficiency.

It was also noted that cold- and hot-carcass yields as well as biological yield had satisfactory values, since the average of these yields in most animals slaughtered in the northeast region of Brazil is between 35.5 and $50.0 \mathrm{~kg} / 100 \mathrm{~kg}$ (Zapata et al., 2001).

Regarding the qualitative characteristics (Table 3), the results are higher than those reported by Garcia et al. (2006), who evaluated the qualitative aspects of carcasses of Anglo Nubian $\times$ UB and Boer $\times$ UB goats and obtained lower values for conformation $(1.5,2.0,1.8$, and 2.5$)$ and for exterior visual impressions $(1.0,1.0,1.0$, and 1.0), indicating that the goats in this study had values comparable to those of crossbred animals, although this type of evaluation was performed subjectively.

Replacing Tifton hay with pineapple stubble hay did not influence $(\mathrm{P}>0.05)$ the kidney-pelvic fat or the marbling of the carcasses of the goats, which presented little marbling, probably due to the energy in the diets, which had an average of $70.25 \%$ TDN, and, according to Berchielli et al. (2006), the energy contained in the diet is rapidly deposited in the animal body. In relation to marbling, studies of Cartaxo et al. (2011) state that it is not increased by the diet; however, it is the genotype that is decisive in improving this characteristic. Therefore, the utilization of only one genotype in this study, i.e., UB, might explain our observations.

According to Furusho-Garcia et al. (2004), the chest depth and the inner-carcass length (Table 4) can be used as indicators of the live weight or the weight of the carcass. Such characteristics have higher values when evaluated in animals with meat production characteristics, which slightly penalizes the animals utilized in this research, which were UB animals.

Researching the qualities of the carcasses of Saanen goats fed a 50:50 roughage:concentrate ratio, Costa et al. (2008) found the morphometric measurements of $55.6 \mathrm{~cm}$ for inner-carcass length and $27.4 \mathrm{~cm}$ for chest depth, which are higher values than those found in this study. The lower measurements observed for the UB goats were likely because the roughage utilized in their diets, pineapple stubble hay, has an inferior nutritional value to that supplied to the Saanen goats (elephant grass), as well as because of the genetic potential of the breed.

The proportion of muscle in the carcass (Table 5) corroborates reports of Cartaxo and Sousa (2008). Lower results were found for loin eye area $\left(7.2 \mathrm{~cm}^{2}\right)$ by Dias et al. (2008), who studied crossbred Anglo Nubian goats with a live slaughter weight of $27.85 \mathrm{~kg}$.

The subcutaneous fat thickness had a decreasing linear effect $(\mathrm{P}<0.05)$, demonstrating a greater protection of the carcasses during cooling for the goats fed the lower level of inclusion of pineapple stubble hay in the diet, suggesting smaller losses by cooling, which was observed in this study.

Subcutaneous fat thickness has a great importance in both the juiciness of the meat and in the protection of the carcass. This characteristic can be directly influenced by 
the intake of nutrients by the animals, mainly energy, as well as by breed characteristics, and the reduction of SFT in this research can be explained by the reduction in the intake of total digestible nutrients in the diets as well as by the type of animal utilized in this study.

Sousa et al. (2009), studying crossbred Anglo Nubian $\times$ UB goats with a hot carcass weight of $12.90 \mathrm{~kg}$, found a lower subcutaneous fat thickness $(1.0 \mathrm{~mm})$ in relation to that of the UB goats in our study.

The carcass compactness index decreased $(\mathrm{P}<0.01)$ linearly with the substitution of Tifton hay for pineapple stubble hay. According to Simela et al. (1999) and Cezar and Sousa (2007), this index can be utilized to evaluate the production of tissues in the carcasses of animals with a similar live weight.

Researching Boer $\times$ Saanen goats slaughtered at an average weight of $33.82 \mathrm{~kg}$, Hashimoto et al. (2007) observed the following mean values: loin eye area of $13.96 \mathrm{~cm}^{2}$, carcass compactness index of $0.25 \mathrm{~kg} / \mathrm{cm}$, and subcutaneous fat thickness of $3.04 \mathrm{~mm}$, similar values to those found for the goats studied here.

The results displayed in Table 6 demonstrate that the goats studied here, despite being slaughtered at different weights, had similar percentages of primal cuts. According to Cezar and Sousa (2007), the leg and the loin are the cuts of highest commercial value, the so-called primal cuts or Grade-A cuts, in view their best muscular yield and tenderer meat. When the results for the commercial cuts are demonstrated in absolute values, it is easier to notice the difference between them; however, when these same results are shown in percentage values, this difference is less noticeable, since the values express how much each cut represents of a determined region of the carcass.

Results higher than those were reported by Ryan et al. (2007) for crossbred Boer goats fed diets with different levels of concentrate $(50,70$, and $90 \mathrm{~g} / 100 \mathrm{~g})$ and with an average hot carcass weight of $14.07 \mathrm{~kg}$. They found the leg yield to be between 26.89 and $31.05 \mathrm{~g} / 100 \mathrm{~g}$, and the shoulder to be between 23.01 and $25.82 \mathrm{~g} / 100 \mathrm{~g}$. The genetic composition and the diet of the goats utilized by these researchers is likely the explanation for these differences.

In general, a decrease in the weights of the leg tissues can be a reflection of the low growth development of the animals with the increase in pineapple stubble hay in the diet, resulting in lighter-weight carcasses. On the other hand, the result obtained for the percentages of muscle, bone and fat indicates that when slaughtered with a body weight between 20.0 and $25.0 \mathrm{~kg}$, the UB goats showed similar tissue proportion.
Studying Indigenous goats with a cold carcass weight of $11.02 \mathrm{~kg}$, Tshabalala et al. (2003) found $76.15,24.59$ and $1.26 \mathrm{~g} / 100 \mathrm{~g}$ of muscle, bone and fat, respectively. Because of the similarity of the cold carcass weight in that mentioned study to the weights found in this present research $(11.68 \mathrm{~kg})$, these results demonstrated that goats of an unknown breed of Northeast Brazil have a lower percentage of muscle $(65.70 \mathrm{~g} / 100 \mathrm{~g})$, similar percentage of bone $(24.64 \mathrm{~g} / 100 \mathrm{~g})$, and higher percentage of fat $(3.38 \mathrm{~g} / 100 \mathrm{~g})$.

\section{Conclusions}

Substitution of Tifton hay for pineapple stubble hay at the level of $33 \mathrm{~g} / 100 \mathrm{~g}$ improves the morphometric, qualitative, and quantitative characteristics of carcasses of goats of an unknown breed subjected to feedlot finishing.

\section{Acknowledgments}

The authors thank EMEPA-PB / FINEP for the support and funding of the research project.

\section{References}

Berchielli, T. T.; Pires, A. V. and Oliveira, S. G. 2006. Nutrição de ruminantes. Funep, Jaboticabal.

Bezerra, S. B. L.; Veras, A. S. C.; Silva, D. K. A.; Ferreira, M. A.; Pereira, K. P.; Almeida, J. S. and Santos, J. C. A. 2010. Componentes não integrantes da carcaça de cabritos alimentados em pastejo na Caatinga. Pesquisa Agropecuária Brasileira 45:751-757.

Cartaxo, F. Q. and Sousa, W. H. 2008. Correlações entre as características obtidas in vivo por ultra-som e as obtidas na carcaça de cordeiros terminados em confinamento. Revista Brasileira de Zootecnia 37:1490-1495.

Cartaxo, F. Q.; Sousa, W. H.; Cezar, M. F.; Costa, R. G.; Cunha, M. G. G. and Gonzaga Neto, S. 2011. Características de carcaça determinadas por ultrassonografia em tempo real e pós-abate de cordeiros terminados em confinamento com diferentes níveis de energia na dieta. Revista Brasileira de Zootecnia 40:160-167.

Cezar, M. F. and Sousa, W. H. 2007. Carcaças caprinas e ovinas: obtenção, avaliação e classificação. 1.ed. Agropecuária Tropical, Uberaba.

Colomer-Rocher, F. 1986. Los criterios de calidad de la canal: sus implicaciones biológicas. In: Papers of the 2 Curso Internacional sobre la Producción de Ovino de Carne, Zaragoza. v.2, p.66.

Costa, R. G.; Medeiros, A. N.; Santos, N. M.; Madruga, M. S.; Cruz, S. E. S. B. S. and Silva, R. G. 2008. Qualidade da carcaça de caprinos Saanen alimentados com diferentes níveis de volumoso e concentrado. Revista Brasileira de Ciências Agrárias 3:186-190.

Dias, A. M. A.; Batista, A. M. V.; Carvalho, F. F. R.; Guim, A.; Silva, G. and Silva, A. C. 2008. Características de carcaça e rendimento de buchada de caprinos alimentados com farelo grosso de trigo em substituição ao milho. Revista Brasileira de Zootecnia 37:1280-1285.

Furusho-Garcia, I. F.; Perez, J. R. O.; Bonagurio, S.; Assis, R. M.; Pedreira, B. C. and Souza, X. R. 2004. Desempenho de cordeiros 
Santa Inês puros e cruzas Santa Inês com Texel, Ile de France e Bergamácia. Revista Brasileira de Zootecnia 33:1591-1603.

Garcia, M. H. O.; Bezerra, F. J.; Santos Filho, J. M.; Rondina, D.; Silva, D. P. G. and Oliveira Filho, J. P. 2006. Aspectos qualitativos das carcaças de caprinos Anglonubiano x SRD e Boer x SRD abatidos em duas faixas de peso. Revista Científica Eletrônica de Medicina Veterinária 3:1-7.

Hadjipanayiotou, M. 1987. Studies on the response of lactating Damascus goats to dietary protein. Journal of Animal Physiology and Animal Nutrition 57:41-52.

Hashimoto, J. H.; Alcalde, C. R.; Silva, K. T.; Macedo, F. A. F.; Mexia, A. A.; Santello, G. A.; Martins, E. N. and Matsushita, M. 2007. Características de carcaça e da carne de caprinos Boer $\mathrm{x}$ Saanen confinados recebendo rações com casca do grão de soja em substituição ao milho. Revista Brasileira de Zootecnia 36:165-173.

Mahgoub, O. and Lu, C. D. 1998. Growth, body composition and carcass tissue distribution in goats of large and small sizes. Small Ruminant Research 27:267-278.

Monte, L. S.; Selaive-Villarroel, A. B.; Pérez, J. R. O.; Zapata, J. F. F.; Bezerra, F. J. and Oliveira, A. N. 2007. Rendimento de cortes comerciais e composição tecidual da carcaça de cabritos mestiços. Revista Brasileira de Zootecnia 36:2127-2133.

Moreira, J. N.; Voltolini, T. V.; Moura Neto, J. B.; Santos, R. D.; França, C. A. and Araújo, G. G. L. 2008. Alternativas de volumosos para caprinos em crescimento. Revista Brasileira de Saúde e Produção Animal 9:407-415.

NRC - National Research Council. 2007. Nutrient requeriments of small ruminants: sheep, goats, cervids, and new world camelids. Washington, D.C.

Piola Junior, W.; Ribeiro, E. L. A.; Mizubuti, I. Y.; Silva, L. D. F.; Sousa, C. L. and Paiva, F. H. P. 2009. Níveis de energia na alimentação de cordeiros em confinamento e composição regional e tecidual das carcaças. Revista Brasileira de Zootecnia 38:1797-1802.

Purchas, R. W.; Davies, A. S. and Abdullah, A. Y. 1991. An objective measure of muscularity: changes with animal growth and differences between genetic lines of southdown sheep. Meat Science 30:81-94.

Ryan, S. M.; Unruh, J. A.; Corrigan, M. E.; Drouillard, J. S. and Seyfert, M. 2007. Effects of concentrate level on carcass traits of Boer crossbred goats. Small Ruminant Research 73:67-76.

Silva Sobrinho, A. G. 1999. Body composition and characteristics of carcass from lambs of different genotypes and ages at slaughter. Dissertation (Post Doctorate in Sheep Meat Production). Massey University, Palmerston North.

Simela, L.; Ndlovu, R. L. and Sibanda, L. M. 1999. Carcass characteristics of the marketed Matebele goat from south-western Zimbawe. Small Ruminant Research 32:173-179.

Sousa, W. H.; Brito, E. A.; Medeiros, A. N.; Cartaxo, F. Q.; Cezar, M. F. and Cunha, M. G. G. 2009. Características morfométricas e de carcaça de cabritos e cordeiros terminados em confinamento. Revista Brasileira de Zootecnia 38:1340-1346.

Tshabalala, P. A.; Strydom, P. E.; Webb, E. C. and De Kock, H. L. 2003. Meat quality of designated South African indigenous goat and sheep breeds. Meat Science 65:563-570.

Yáñez, E. A.; Resende, K. T.; Ferreira, A. C. D.; Medeiros, A. N.; Silva Sobrinho, A. G.; Pereira Filho, J. M.; Teixeira, I. A. M. A.; and Artoni, S. M. B. 2004. Utilização de medidas biométricas para predizer características da carcaça de cabritos Saanen. Revista Brasileira de Zootecnia 33:1564-1572.

Zapata, J. F. F.; Seabra, L. M. A. J.; Nogueira, C. M.; Bezerra, L. C. and Beserra, F. J. 2001. Características de carcaça de pequenos ruminantes do nordeste do Brasil. Ciência Animal 11:79-86. 